\title{
ESTABLISHMENT OF NEW MONASTERIES ON "THE CAUCASIAN LINE" OF THE RUS- SIAN EMPIRE IN THE MIDDLE OF THE 19TH CENTURY: ON THE EXAMPLE OF MARY MAGDALENE CONVENT
}

\author{
(c) Pavel G. Nemashkalov \\ State-Funded Educational Institution of Higher Education \\ "Stavropol State Teacher's Institute", Stavropol, Russian Federation \\ science-almanac@mail.ru
}

In the territory of the North Caucasus there was the Caucasian War for decades. That's why the Caucasian line was populated by natives not only of different parts of the empire, but it also became a shelter for representatives of other peoples and states. As a result, the language and religious differentiation in the region was quite notable that could not but lead to maintaining ethnic consciousness. The crisis public phenomena found the reflection in the religious sphere. Having become "warm Siberia", it involved to its territories a large number of representatives of split and various sects which could feel more freely here, than in the central provinces of the empire. Realizing the current situation, for the purpose of overcoming the cultural dissociation and inclusions of new territories into the uniform system of the public relations, the government undertook a number of measures among which there was a creation of the independent Caucasian and Black Sea diocese in 1843. After the deep church crisis in which there were many parishes of the North Caucasus and with the formation of the independent diocese, the religiousness of the population increased. It also found reflection in the development of monastic activity through the restoration of old monasteries and institution of new. The convent of Mary Magdalene became one of such "phenomena" in the North Caucasus. It didn't find broad support in the Cossack region at once, but having received the help from the diocesan and army power, it could not only overcome and break the approved stereotypes in consciousness of the population concerning the position of the woman in the society, but also promoted the approval of Orthodox faith and church authority in the environment of the motley population of the region. In many respects these processes formed a basis of the arisen contradictions with army board and they did not find support in organs of supreme authority, however, there was no other way of overcoming the developed contradictions. One of the conditions of establishment of Mary Magdalene Convent was its construction exclusive on means received in the form of donations and alms, and also income from own agricultural and work activity. The construction of the convent was supposed to be conducted on these means, without taking in attention that the convent was forced to keep the staff of sisters, novices and workers, pilgrims and sufferers. Overcoming all economic difficulties, the convent promoted the growth of the authority of Orthodox faith and restoration of the church order in the North Caucasus. convent.

Key words: History of the Russian Orthodox Church, Northern Caucasus, the Black Sea Mary Magdalene

\section{[П.Г. Немашкалов Учреждение новых монастырей на "кавказской линии" Российской империи в середине XIX века: на примере Марие-Магдалиновской обители]}

На территории Северного Кавказа не первое десятилетие шла Кавказская война, из-за чего Кавказская линия была заселена выходцами не только из разных частей империи, но и стала прибежищем представителям других народов и государств. Вследствие чего языковая и религиозная дифференциация в регионе была довольно ощутимой, что не могло не вести к сохранению этнического самосознания. Кризисные общественные явления нашли отражение в религиозной сфере. Став «теплой Сибирью», привлекал на свои территории большое число представителей раскола и различных сект, которые могли здесь чувствовать себя более свободно, чем в центральных губерниях империи. Осознавая сложившуюся ситуацию, с целью преодоления культурной разобщенности, и включения новых территорий в единую систему общественных отношений правительством предпринималось ряд мер, в числе которых было создание в 1843 году самостоятельной Кавказской и Черноморской епархии. После глубокого церковного кризиса, в котором оказались многие приходы Северного Кавказа, с образованием самостоятельной епархии происходит подъем религиозности населения. Это нашло отражение и в развитии монастыр- 
ской деятельности, через восстановление старых обителей и учреждение новых. Одним из таких «явлений» на Северном Кавказе стал Марие-Магдалиновский женский монастырь. Не сразу найдя широкую поддержку в казачьем регионе, но получив помощь со стороны епархиальной и войсковой власти, он смог не только преодолеть и переломить утвердившиеся стереотипы в сознании населения относительно положения женщины в обществе, но и способствовал своей деятельностью утверждению православной веры и церковного авторитета в среде пестрого населения региона. Во многом эти процессы послужили основой возникших противоречий с войсковым правлением и не находили поддержки в органах высшей власти, однако, другого пути преодоления сложившихся противоречий не было. Одним из условий учреждения Марие-Магдалиновской женской обители было её строительство исключительно на средства, полученные в форме пожертвований и подаяний, а также доходов от собственной сельскохозяйственной и трудовой деятельности. Строительство монастыря предполагалось вести на эти средства, не беря во внимание, что обитель была вынуждена содержать штат сестер, послушниц и работников, паломников и страждущих. Преодолевая все экономические трудности, монастырь способствовал росту авторитета православной веры и восстановлению церковного порядка на Северном Кавказе.

Ключевые слова: История Русской Православной Церкви, Северный Кавказ, Черноморский МариеМагдалиновский женский монастырь.

Pavel G. Nemashkalov - Ph.D. in History, Associate Professor, Stavropol State Teacher's Institute, Stavropol, Russian Federation.

Немашкалов Павел Григорьевич - кандидат исторических наук, доцент, Ставропольский государственный педагогический институт, г. Ставрополь, Российская Федерация.

The first monasteries appear in the North Caucasus with the first system attempts of colonization of the region. The emergence of men's Kizlyar Monastery of the Exaltation of the Holy Cross is connected with abolition of fortress of the Sacred cross on the Sulak River under the Treaty of Ganja between Russia and Iran in 1735 and transfer of garrison of the fortress together with the administrative agencies in the founded city of Kizlyar [16, p. 192]. As the city had an important strategic position, with the structure of monastery it quickly had become the center of distribution of Orthodoxy which "gave the chance to experience and realize the valuable changes which took place in this axiological structure" [11, pp. 116-120]. In addition, the city was the secret capital of all North Caucasus.

In respect of distribution of the Christianity promoting "... the advance of orthodox religious moral values" [17, pp. 94-95], and the formation of "... a religious form of consciousness" [12, pp. 76-80], in the region there was the Mozdok fortress in which non-Christian were not let to reside. The men's Preobrazhensky Mozdok Monastery, founded in 1763, at a certain period of time also became the center of Christian life. In 1797 for the first time in the North Caucasus, at the establishment of the independent Mozdok diocese, at Assumption Church, the convent was opened according to the decree of Catherine II [15, pp. 211, 288]. Restless time did not give the chance to show the capacity of these monasteries as in 1799 both of them were abolished. However, their existence in the most unexpected way will play a crucial role in opening of the Black Sea Mary Magdalene convent.

Position of monasteries was defined by the "monastic reforms" undertaken in the period of Catherine II since 1764 when the decree about the spiritual states was issued under which practically all property of monasteries was confiscated in favor of the State, and their number in Russia was sharply reduced. The great Russian poet and writer A.S. Pushkin gave a negative assessment of the public policy in this field. In particular, he wrote that Catherine II undertaking such reforms, struck a great blow to the national education. As a result, of these "transformations" many seminaries fell into decay, in villages there were not enough educat- 
ed priests, as a result, contempt for priests and indifference to religion appeared among the people. Monkhood, according to him, had a big role in the history of our country and in education of the people [23, p. 130]. Actually each destroyed monastery stored historical monuments, wonder-working icons, national legends, and these monasteries were an integral part of history of the certain territory of the huge country, they had an impact on "their manifestations in art creativity, religion and philosophy" [13, pp. 98-104].

Trying to soften the consequences of such nature of cardinal transformations, even in the period of reign of Catherine II several decrees were issued, they improved the position of monasteries: it was allowed to open new monasteries and to renew former. Paul I in 1797 allowed to increase monastic allotments to 30 tithes and also to have the mills and fish ponds, doubled the maintenance of monasteries, even unimportant monasteries began to receive up to 300 rubles a year from treasury. For the North Caucasus the special provisions which could change some norms were issued.

The region tormented by the war was filled with grief of its people. In search of a consolation and healing of soul, women and girls left the native land forcedly, looking for the grace of God in monasteries of other dioceses. On the first trip around the region the bishop noted high religious spirit of the population, its aspiration to knowledge of God and lack of granting of such opportunity from the available church and monastic infrastructure. So, for example, widows and girls went to the bishop Jeremiah and asked him to open convents in the region. There were cases when they under the influence of feeling of belief, gathered at nights and made prayers, read lectures and psalters for visitors of their meetings. Some of them appealed to a consistory to arrange monastic female lodges at churches, but the church authorities forbade such gatherings and demanded from archpriests not to allow them, but in practice it was very difficult.

It seemed that the problem was solved after the establishment of Ioanno-Mariinska female community in Stavropol in memory of the parents by eminent Jeremiah. However, in 1849 in the Prikumsky settlements the night gatherings were revealed, and two men who collected donations for the opening of the convent in Georgiyevsk were detained soon. The Pyatigorsk territorial court, according to Jeremiah's application, stopped investigative actions and released defendants from custody as Jeremiah saw in them "diligent Christians to the Christ's church" [8, I.1-7].

In such difficult situation, only by a fluke of providence, Mary Magdalene convent was founded in the Black Sea region. This case took place in July, 1846, when the nun of Ladanskago monastery of the Poltava province, Mitrofaniya was engaged in fund raising in the native land from the specified monastery. On this issue she met in Yekaterinodar with the ataman of the Black Sea army, the major general G.A. Rashpil, and could convince him of need of opening of such monastery for the Black Sea region, promising to arrange it only on the donations and charitable collecting.

In the official report he wrote to the top military commander of the Caucasian line and of the Black Sea region, to the lieutenant-general and commander N.S. Zavadovsky that after the resettlement of Zaporozhian Cossacks to the land of Kuban, they did not lose diligence to the Orthodox belief. Having founded the men's monastery at the end of the 19th century, based on the requirement of a female part of the population, now they want to base the women's monastic monastery for the army inhabitants [4, I. 1-2ob.].

This monastery, according to him, will maintain the national diligence to religion in the army. Helpless monks and widows which lost husbands or children, which also have other irrevocable losses in their life will find the last consolation of a prayer and the Christian help in it. At absence, at that time, of both public, and private women's educational institutions in the army, the convent, as well as men's Nikolaev monastery in due time, could become the place of education of female monasticism. 
To begin such large-scale enterprise as construction of the monastery without any means was not only risky, but also hopeless, especially for the North Caucasus in the conditions of the military conflict. Understanding this situation, the lieutenant-general N.S. Zavadovsky gave orders to give 20 thousand rubles of silver at a time from the army fund to the credit bank for 20 years for the organization of this convent. Interest earnings were transferred to the account of the convent that made annually about 800 rubles [9, I. 5-5ob.]. Every year the diocesan management had to report on the made expenses from this sum to the army board, and after the fixed time these means had to be returned back to the Black Sea army.

The begun official red tape about opening of the convent encountered existing rules of the legislation in the Russian Empire. According to the provisions of the law, establishment of new monasteries was allowed in the diocese, only if the staff of the monasteries is transferred from any closed in the internal province. At that time there were not such monasteries, therefore the solution of this question was postponed for indefinite time and could delay for many years.

The solution of this problem was found by the eminent Jeremiah. In his appeal to the Governing bodies of the region and to the Synod on the 7th of October, 1846, he paid attention that there was not any spiritual and moral establishment for a female in such extensive region, and establishment of the Black Sea convent would be restoration of that second-class convent which existed in the city of Mozdok at the end of the 19th century. This convent could become the place of education of the poor and the orphan maidens of army clergy [4, I.16-16ob.]. Undoubtedly, this condition of the bishop contradicted the initial program of establishment at the monastery of a boarding house for education of girls from military class, but the need of opening of the convent allowed deviation of the army management from initially set conditions.

Correspondence had continued nearly for two years and a half, and only on the 11th of December, 1848, the emperor Nicholas I, owing to the report of the Council of War, allowed the establishment of the convent for the sake of St. Mary Magdalene in the Black Sea region [24, p. 653]. This convent intended for female persons of military class.

By initially, the army board transferred 171 tithes of the land and 55 waters to the possession of the established convent, but at land surveying of the site it became clear that the area of an estimated to the transfer of the territory differed from the site plan approved by the emperor. Ataman G.A. Rashpil wrote in his explanation that the made and presented land plan of the establishment of the convent was made "by eye" because in the army there were no experts familiar with topography. As a result of all agreements, all the piece of the army land in 522 dessiatins 315 sazhens on the Kiprili River was transferred to the convent [19].

On the allocated site of the army land for the convent there was a stud farm. All its property consisted in a small lodge, adjacent farm buildings and an orchard. According to the inventory list the stud farm with all the "junk" was estimated at 47.69 rubles, and the land with all buildings and vegetation was estimated at 202.49 rubles [3, I.162]. Thus, it is possible to claim that the convent got the waste ground of the land on which it was necessary to build a church and buildings suitable for life as soon as possible.

The founded Mary Magdalene convent got a degree of the second-class monastery and the staff of 22 churchmen was established. It included Mother Superior, the treasurer, 15 nuns and the full church clergy consisting of the priest, the deacon and two junior deacons with a woman making communion bread. From the army 8 churchmen from Cossacks of the internal armed forces for monitoring the economies and for the performance of the current works on the arrangement of the convent were appointed. For the housekeeping needs of the convent it was allowed to mine 300 poods (one pood equaled 16,38 kg) of salt in the army 
lakes, but only with introduction of the established excise. When the convent achieved financial independence it was allowed to ask about opening of a female boarding house. By agreement with nuns of the convent the army class was granted the primary right to send the children to get education in the convent. It was especially noted that in all questions the convent consisted in the direct guidance of the spiritual authorities of the diocese on the general rules [20]. The army did not undertake obligations for construction of buildings of the convent and a sacristy, exclusively purse-seine funds, raised donations and candle profit were directed for these needs [9, I.5-5ob.]. The salary in a total amount of 470 rubles a year was paid to the regular churchmen [18].

The importance in such responsible and large-scale business as the organization of the convent, begun by the ataman G.A. Rashpil, depended not only on him, but more on the person who was capable to implement the shaped plans. Coincidentally such person initially was near and was capable for their realization. The general in his first official report petitioned for the appointment of the nun Mitrofaniya to the management of the established convent, she guaranteed success and promised to organize the convent only on donations.

The nun Mitrofaniya was from an old noble family, she studied reading and writing in the house of her parents. In 1826, having become a widow in the Black Sea army in the city of Yekaterinodar, of her own accord she left Army and went to the Russian monasteries, and on the 25th of October, 1833, she was defined by the Poltava diocesan administration to the Ladansky Pokrovsk convent where in a year she was covered with rassaphore, and on the 27 th of January, 1841, she was admitted to the veil. Since 1843 till 1849, according to the order of Mother Superior, she was sent to many provinces of the Russian Empire with the pleading book for collecting donations in favor of the Ladansky convent. For devotion and execution of the duties assigned to her in the same convent she was defined as a decent, and on the 16th of July, 1849, she was transferred to the Black Sea army to the established Mary Magdalene convent by Mother Superior [1, I.24].

To disseminate doubts of the eminent Jeremiah in the choice of the candidate, the person practicing a position of the ataman to his letter attached the letter of Mother Superior of the Ladansky convent to his wife Carolina Adamovna. In this letter Mother Superior Maria characterized the nun Mitrofaniya as follows: "my spiritual daughter who had been living for a long time in the convent, leading monastic life and excellent and jealous obedience for the benefit of the convent and deserved there a rank of decent of the convent $<\ldots>$ prepared her for my place" [3, I.113-113ob.]. The bishop who most of all appreciated time and worthy people of the dignity, noted in his answer that he not only agreed with the Poltava diocesan authorities, but that "he prepared a crosier which was ready to hand to the recommended nun as soon as she would be able to arrive in Stavropol" [24, 658 p.].

For the organization of this convent Mother Superior Mitrofaniya arrived at the land of the Black Sea Cossacks with seven sisters among which there were two nuns, Filareta and Rafaila. Many of them looked bewildered at the beginning of the business, they knew that the undertaken organization of the whole monastic desert on the empty place is an important business, they knew even that the real and assumed means were not reliable. Therefore, initially every year the consistory gave two books and passports for the movement on the name of the nuns of the convent who went in the internal provinces of the Russian Empire for collecting donations. In the first years the rassophore nun Ananiya with the novice Ulyana and the rassophore nun Pakhomiya with the novice Irina were defined among the sisters of the convent [7, I.10, 37, 43]. For the construction of the stone temple for the sake of Mary Magdalene the funds were raised in the Caucasian and Novocherkassk dioceses by the nun Kalisfena and by the rassophore novice Magdalene [7, I.55]. 
Different philanthropists among whom there were not only civilians, and mostly the Cossacks of the lowest and top ranks brought various amount of donations. Contributions from the Cossacks bearing cordon service were received, they deducted from the received salary a part of the sum in the amount from 10 to several hundred rubles. Cossack village's societies and individuals of the Black Sea army donated not only money, but also construction material and also another necessary for settlers on the new place objects of use. Since 1849 till 1850 the convent got about 9100.4 rubles of silver from different persons [3]. The big role of collecting of these means belongs to the ataman G.A. Rashpil who spread invitation sheets in favor of the convent to different regiments, battalions and batteries of the Black Sea army. With his mediation the convent got access to the construction army resources from which the convent bought necessary construction materials at minimum price [3, I. 242-242ob., 332, 379].

On the 21st of September, 1849, on Day of the saint bishop and wonder-worker Dmitry Rostovsky, solemn putting of the base of the first temple was made. The prior of the Ekaterino-Lebyazhesky Nikolaev desert, Archimandrite Dionysius, with nine priests from the Black Sea, sanctified this process [24, 655 p.]. Works on its installation were conducted so quickly that sanctifying of the built wooden temple on the brick base took place on the 9th of April, 1850. Materials of the old church of the society of Starokorsunsky Cossack village which conceded it at the bargaining to the priest I. Zolotarenko for 500 rubles of silver were taken in its basis [3, I.160]. By autumn in the territory of the convent the wooden outhouse on the brick base with 7 rooms covered by iron for the room of Mother Superior was built. Two monastic cells for nuns were also built, they were covered with wood boards, the first one was with 11 and the second one was with 8 rooms $[3,1.53,61]$. Speaking about the nature of these buildings it is possible to see that they were temporary, and adjustment of monastic life and church services was the main goal.

About the popularity of the arranged convent it is possible to judge by the fact that Mother Superior Mitrofaniya in the special official report in spring of 1851 asked the bishop Ioannikiy for permission to arrange separate hotel for "pious visitors", there were more and more of them each year as the convent was the only one in the Black Sea region [3, I.12]. The eminent Jeremiah wrote in his reports about the condition of the diocese that the Black Sea Mary Magdalene convent "had been increasing with success with the help of care of Mother Superior and with the help of the diligence of the army inhabitants due to which this convent appeared and was provided with means" [5, I. 7ob.].

The size of floating assets of the convent at that time was a little more than 4 thousand rubles [6, I. 6-7], and the size of means directed for the organization of an iconostasis and its maintenance in an appropriate look reached 366 rubles [6, I. 8-9]. Despite limitation in means and resources in 1861 the second temple of the convent was sanctified in honor of the heavenly patroness of the convent, Saint Mary Magdalene Equal to the apostles. The archpriest building was added to it. In 1867 Mother Superior Mitrofaniya, full of spiritual eagerness and progress in building, petitioned for the permission of building of the temple in honor of the Acheiropaeic Image, but the petition was rejected because of a lack of means. But it did not stop Mother Superior in the subsequent undertaking of building in the convent of Ascension Cathedral with three thrones of God with side chapels in honor of Saint God's Archistrategos Mikhail and Saint Dimitry Rostovsky whose Memorial Day, as it was already told before, was considered as a day of foundation of the Black Sea Mary Magdalene convent. This petition also did not find support of the diocesan management in 1865, and only on the 23rd of August, 1873, it was authorized to build the stone cathedral temple in honor and memory of Ascension in the Black Sea Mary Magdalene female desert [21, p. 560]. 
The first Mother Superior, who made a lot of things for the development of the convent, was not fated to see all those monumental majestic buildings and the reached authority of the convent because Mother Superior Mitrofaniya died on the 10th of March, 1869, on the 74th year of life. During the service as Mother Superior she repeatedly received deserved official messages of gratitude from the diocesan administration. So, on the 25th of October, 1852, the eminent loanniky, the Caucasian bishop and the Black Sea commander expressed head pastor's gratitude "for reasonable activities for the organization of a new convent". However, the progress of the convent was estimated not only by the local diocesan government, on the 21st of May, 1853, the Synod thanked Mother Superior for diligent service, and on the 16th of June, 1857, for excellent and diligent service she was awarded with a pectoral gold cross [5, I.24].

Mother Superior Olympiada took her place, she was from noblemen of the Kuban Cossack army, she continued the begun business adequately. She managed to complete Ascension Cathedral, and further to show jealous diligence performed by the duties assigned to her. On the 1st of April, 1878, for merits on spiritual department Mother Superior Olympiada was awarded with the favoring of the Synod of the Black Sea Mary Magdalene female desert [22, p. 272]. On the 20th of April, 1880, she, as well as her predecessor Mother Superior Mitrofaniya in 1857, on a submission from the Synod was awarded with an award, a pectoral cross.

Where before there was one desert peninsula, at the end of the 19th century, the wellplanned monastic convent with a very strong fencing impressed everybody by its beauty. Behind this fencing there are a wooden cold building and a brick warm building, beside the house of the Mother Superior there are churches with the wooden bell tower. "Churches are not rich, but quite satisfy the needs of the desert. The church service in them is made with sightliness and discipline; there is such a rare separateness in reading and singing, and there is not the delicacy which so strongly influences the soul and pleasantness in songs which are heard every day during the religious rites. In the Black Sea Mary Magdalene desert on festive days and on Sundays there are always two liturgies. All ceremonial religious rites are made under the ordinary church canons without the slightest omission. After the major services they sing sacred Angelic Salutation: "oh all-knowing mother, and not imams other help" with very pleasant tune [24, pp. 683-690].

In the process of going of the Russian troops deep into the Caucasus the attached territory grew, and together with it the number of the Cossack and country settlements demanding the formation of new parishes grew. The mission of the pacification of the rebellious variegated population, and the ensuring the state control of its movement was assigned to clergy and monasteries of the Caucasian and Black Sea diocese because the army administration coped quite badly with it. Besides, religion being "a form of public consciousness ..., defining ... the spiritual sphere of the person" [14, pp.142-146], softened severe military everyday life, and at the same time gave them intelligence and expediency, "... provided education of the positive attitude towards cultural distinctions, understanding of interdependence of the people ..." [10, pp. 7-10].

Development of convents was interfered by that circumstance that in the military region there was catastrophically not enough female population. The first attempts of establishment of such monasteries at the end of the 18th century did not get support among the population and were stopped further. By the time of establishment of the independent Caucasian diocese the conditions for development of women's self-sacrifice had been already created. The first established convents experienced big difficulties in development of material resources, but it did not block the growth of their spiritual influence on the adjoining territories and the population at all. 


\section{Лumepamypa}

1. Государственный архив Краснодарского края (Далее - ГАКК). Ф. 318. Оп. Д.313.

2. ГАКК. Ф.249. Оп.1. Д.1911.

3. ГАКК. Ф.249. Оп.1. Д.2869.

4. ГАКК. Ф.318. Оп.1. Д.313.

5. Государственный архив Ставропольского края (Далее - ГАСК). Ф.135. Оп. 16. Д.2.

6. ГАСК. Ф.135. Оп.22. Д.638.

7. ГАСК. Ф.135. Оп.4. Д.212.

8. ГАСК. Ф.135. Оп.7. Д.195.

9. ГАСК. Ф.135. Оп.8. Д.268.

10.Говердовская E.B. Особенности проектирования образовательного пространства высшей школы в поликультурном регионе // Экономические и гуманитарные исследования регионов. 2014. № 4. С. 7-10.

11.Гончаров В.Н. Социально-философский анализ процесса модернизации в контексте аксиологических трансформаций общественных отношений // Экономические и гуманитарные исследования регионов. 2019. № 1. С. 116-120.

12. Ерохин А.М. Социально-философский анализ этнографического исследования ранних форм религии славян // Экономические и гуманитарные исследования регионов. 2017. № 6. С. 76-80.

13. Камалова О.Н. Вл. Соловьев об интуиции и ее специфике в художественном творчестве, фрилософиии и религии // Экономические и гуманитарные исследования регионов. 2013. № 3. С. 98-104.

14. Колосова О.Ю., Жикривецкая Ю.В. Наука и религия: социокультурный аспект // Экономические и гуманитарные исследования регионов. 2016. № 2. С. 142-146.

15. Материал для историко-топографического исследования о православных монастырях в Российской империи с библиографическим указателем / Составит. и изд. В.В. Зверинский. Ч.1: Преобразование старых и учреждение новых монастырей с 1764-1895 по 1 июля 1890 год. СПб., 1890.

16. Материал для историко-топографического исследования о православных монастырях в Российской империи с библиографическим указателем / Составит. и изд. В.В. Зверинский. Ч. 2: Монастыри по штатам 1764, 1786 и 1795 годов. СПб., 1892.

17. Несмеянов E.E. Проблема преподавания религиоведения и духовно-нравственной культуры в поликонфессиональном регионе // Гуманитарные и социальноэкономические науки. 2010. № 3(52). С. 94-95.

18. О назначении еще другого Священника в женскую пустынь во имя Св. Марии Магдалины, находящуюся в Черноморском казачьем войске (22 февраля 1854 г.) // Полное собрание законов Российской империи (Далее - ПСЗРИ) (1825-1881). Т. 29: Ч. 1. №27958.

19. О приобретении на счет станичных сумм училищных потребностей для станичных школ Оренбургского казачьего войска (12 августа 1850 г.) // ПСЗРИ (1825-1881). Т. 25: Ч. 1. № 24402.

20.О учреждении в Черноморском казачьем войске женской обители во имя Святой Марины Магдалины (11 декабря 1848 г.) // ПСЗРИ (1825-1881). Т. 23. № 22812.

21. Отдел официальный. Распоряжения Епархиального начальства // Кавказские епархиальные ведомости. 1873. № 17. 1 сентября. С. 560.

22. Отдел официальный. Распоряжения Епархиального начальства // Кавказские епархиальные ведомости. 1878. №8. 15 апреля. С. 272.

23. Пушкин А.С. Полное собрание сочинений. Т. 8. М., 1958. 
Научный альманах стран Причерноморья. 2019. Том 19. № 3

24. Св. Филипп Николайченко Очерк Черноморской Марие-Магдалинской женской пустыни // Кавказские епархиальные ведомости. 1874. № 20. 16 октября. С. 649-658.

\section{References}

1. Gosudarstvennyi arkhiv Krasnodarskogo kraia (Further - GAKK) [The Public archive of Krasnodar Krai] F. 318. Op. D.313.

2. GAKK [The Public archive of Krasnodar Krai] F.249. Op.1. D.1911.

3. GAKK [The Public archive of Krasnodar Krai] F.249. Op.1. D.2869.

4. GAKK [The Public archive of Krasnodar Krai] F.318. Op.1. D.313.

5. Gosudarstvennyi arkhiv Stavropol'skogo kraia (Further - GASK) [The Public archive of Stavropol Krai] F.135. Op. 16. D.2.

6. GASK [The Public archive of Stavropol Krai] F.135. Op.22. D.638.

7. GASK [The Public archive of Stavropol Krai] F.135. Op.4. D.212.

8. GASK [The Public archive of Stavropol Krai] F.135. Op.7. D.195.

9. GASK [The Public archive of Stavropol Krai] F.135. Op.8. D.268.

10. Goverdovskaia E.V. Osobennosti proektirovaniia obrazovatel'nogo prostranstva vysshei shkoly v polikul'turnom regione. Ekonomicheskie i gumanitarnye issledovaniia regionov. [Features of design of educational space of the higher school in the polycultural region. Economic and humanitarian researches of regions]. 2014. No. 4. pp. 7-10 (in Russian).

11. Goncharov V.N. Sotsial'no-filosofskii analiz protsessa modernizatsii v kontekste aksiologicheskikh transformatsii obshchestvennykh otnoshenii. Ekonomicheskie i gumanitarnye issledovaniia regionov. [The social and philosophical analysis of process of modernization in the context of axiological transformations of the public relations. Economic and humanitarian researches of regions]. 2019. No. 1. pp. 116-120 (in Russian).

12. Erokhin A.M. Sotsial'no-filosofskii analiz etnograficheskogo issledovaniia rannikh form religii slavian. Ekonomicheskie i gumanitarnye issledovaniia regionov. [Social and philosophical analysis of an ethnographic research of early forms of religion of Slavs. Economic and humanitarian researches of regions]. 2017. No. 6. pp. $76-80$ (in Russian).

13. Kamalova O. N. VI. Solov'ev ob intuitsii i ee spetsifike v khudozhestvennom tvorchestve, filosofii i religii. Ekonomicheskie i gumanitarnye issledovaniia regionov. [VI. Solovev about an intuition and its specifics in art creativity, philosophy and religion. Economic and humanitarian researches of regions]. 2013. No. 3. pp. 98-104 (in Russian).

14. Kolosova O.Iu., Zhikrivetskaia Iu.V. Nauka i religiia: sotsiokul'turnyi aspect. Ekonomicheskie i gumanitarnye issledovaniia regionov. [Science and religion: sociocultural aspect. Economic and humanitarian researches of regions]. 2016. No. 2. pp. 142-146 (in Russian).

15. Material dlia istoriko-topograficheskogo issledovaniia o pravoslavnykh monastyriakh $\mathrm{v}$ Rossiiskoi imperii s bibliograficheskim ukazatelem [Material for a historical and topographical research about orthodox monasteries in the Russian Empire with the bibliographic index]. Sos. and prod. V.V. Zverinsky. Ch.1: Transformation old and establishment of new monasteries from 1764-1895 to July 1, 1890. Saint Petersburg, 1890.

16. Material dlia istoriko-topograficheskogo issledovaniia o pravoslavnykh monastyriakh $v$ Rossiiskoi imperii s bibliograficheskim ukazatelem [Material for a historical and topographical research about orthodox monasteries in the Russian Empire with the bibliographic index]. Sos. and prod. V.V. Zverinsky. Ch.2: Monasteries on states 1764, 1786 and 1795. Saint Petersburg, 1892.

17. Nesmeianov E.E. Problema prepodavaniia religiovedeniia i dukhovno-nravstvennoi kul'tury v polikonfessional'nom regione. Gumanitarnye i sotsial'no-ekonomicheskie 
nauki. [A problem of teaching religious studies and spiritual and moral culture in the polyconfessional region. Humanitarian and social and economic sciences]. 2010. No. 3(52). pp. 94-95 (in Russian).

18. O naznachenii eshche drugogo Sviashchennika v zhenskuiu pustyn' vo imia Sv. Marii Magdaliny, nakhodiashchuiusia v Chernomorskom kazach'em voiske (22 fevralia 1854 g.) [About appointment still other Priest in women's deserts for the sake of St. Mary of Magdalene, being in the Black Sea Cossack army (on February 22, 1854)]. Complete collection of laws of the Russian Empire (Further - PSZRI) (1825-1881). V. 29: Ch.1. No. 27958.

19. O priobretenii na schet stanichnykh summ uchilishchnykh potrebnostei dlia stanichnykh shkol Orenburgskogo kazach'ego voiska [About acquisition into the account of the stanitsa sums of requirements of training school for stanitsa schools of the Orenburg Cossack army (on August 12, 1850). PSZRI (1825-1881). V. 25: Ch.1. No. 24402.

20. O uchrezhdenii v Chernomorskom kazach'em voiske zhenskoi obiteli vo imia Sviatoi Mariny Magdaliny (11 dekabria 1848 g.) [About establishment in the Black Sea Cossack army of a convent for the sake of Saint Mary Magdalene (on December 11, 1848). PSZRI (1825-1881). V. 23. No. 22812.

21. Otdel ofitsial'nyi. Rasporiazheniia Eparkhial'nogo nachal'stva. Kavkazskie eparkhial'nye vedomosti. [Official department. Orders of the Diocesan administration. Caucasian diocesan sheets]. 1873. No. 17. September 1. 560 p.

22. Otdel ofitsial'nyi. Rasporiazheniia Eparkhial'nogo nachal'stva. Kavkazskie eparkhial'nye vedomosti. [Official department. Orders of the Diocesan administration. Caucasian diocesan sheets]. 1878. No. 8. April 15. 272 p.

23. Pushkin A.S. Polnoe sobranie sochinenii. [Complete works]. V.8. Moscow, 1958 (in Russian).

24.Sv. Filipp Nikolaichenko Ocherk Chernomorskoi Marie-Magdalinskoi zhenskoi pustyni. Kavkazskie eparkhial'nye vedomosti. [Sketch of the Black Sea Mary Magdalene female desert. Caucasian diocesan sheets]. 1874. No. 20. October 16. pp. 649-658 (in Russian). 